\title{
Juli Zeh's Corpus Delicti: Between Dystopia/Utopia and Coronavirus crisis
}

\author{
Alexandra Juster \\ University of Córdoba, Spain
}

\begin{abstract}
Juli Zeh's Corpus Delicti, published in 2009 in Germany, is often cited as a significant contemporary dystopia. The author paints a health dictatorship in the midst of the 21 st century, where everybody is in perfect health and ignores the feeling of pain, but as a counterpart there is no individual freedom, insofar as collective interests prevail. For the sake of eradication of any form of illness, all citizens have to respect strict sanitary rules and notify health data to the authorities. The purpose of perfect health and painless life without fear of diseases as legitimization of a totalitarian system seems to be in harmony with human's desire to survive the longest possible. Research about what dystopia in literature is and the fit of dystopian literary definition with Corpus Delicti. Investigation about possible utopian and new dystopian features which come to complete the dystopian genre, with a glance to the present. Indeed, the idyllic, clean world without tracks of pollution seems utopian, while the current battle against the Corona virus crisis by democratic countries seems to confirm Zeh's dystopian visions about strong restrictions or loss of individual rights, through legal misleads. France's management of the Corona crisis as an example of the danger to compromise democratic achievements.
\end{abstract}

Keywords: Juli Zeh's Corpus Delicti, literary genre of utopia/dystopia, current Corona crisis, example of France's crisis management

\section{Purpose}

The purpose of the present document is to investigate utopian/dystopian features of Corpus Delicti as well as its visionary character with respect to the current Corona virus crisis, focusing on its consequences, from the legal point of view, on our individual rights.

The restriction of the latter will be demonstrated by the example of France's legislation and management in order to fight Covid-19.

Juli Zeh is a contemporary German author with a legal and literary education, who has become very engaged with socio - political issues in Western society. She defends especially human's individual rights, which are more and more threatened by digital supervision (Ilija Trojanow et al., 2009).

Corpus Delicti is her first political work, which draws a Health dictatorship, the METHOD, aiming to force every citizen, by instruments of permanent invigilation, to stay in perfect health. No diseases, no illness, no pain shall further trouble humanity. As a counterpart of this supposed "happiness", individual prerogatives must surrender to collective interests: 
Es liegt in Ihrem Interesse, jede Form von Krankheit zu vermeiden. In dem Punkt decken sich Ihre Interessen mit jenen der METHODE, und auf diese Übereinstimmung stützt sich unser gesamtes System. Es besteht eine enge Verbindung zwischen dem persönlichen und dem allgemeinen Wohl, die in solchen Fällen keinen Raum für Privatangelegenheiten lässt (Zeh, 2013: 63-64)".

Mia Holl, a 34 years old biologist, is cited several times in court for non-compliance with health reporting obligations. She is known to the court as the sister of Moritz, who professed selfdetermination and personal freedom as a freethinker, refusing absolute obedience to the METHOD. Moritz becomes the victim of a miscarriage of justice and is wrongly sentenced for murder. Faithful to his motto that life is an offer we can refuse - "Das Leben ist ein Angebot, das man auch ablehnen kann (Zeh, 2013: 31)"-, he commits suicide in his prison cell thanks to Mia's smuggling in of a transparent fishing line. Shortly before committing suicide, he gives Mia his "ideal lover", die "Ideale Geliebte", in whose invisible form he lives on for Mia.

Deeply depressed about Moritz' death, Mia neglects her reporting duties and demands just to be "left in peace" the time she recovers from her emotional pain, believing that such a need is a private issue: "Ich hielt meinen Schmerz für eine Privatangelegenheit (Zeh, 2013: 58)".

At this stage Mia realises how much the METHOD suppresses individual rights and gradually turns away from the system until becoming an open opponent to the system from the moment the innocence of Moritz could be proved, revealing the METHOD to be unreliable.

In just 264 pages Juli Zeh deals with an incredible wealth of socio-political topics and seems to anticipate the today's Corona virus crisis: human nature and its needs, individual freedoms, self-determination, totalitarianism, feelings and emotions in a mechanised world, the relationship to our bodies, the body as a political instrument of power, manipulation by the media, the jurisdiction, the legal norm and its interpretation, environmental protection, health and its place in society, the hierarchisation of values, individualism vs. collectivism and much more.

In the following, after a short description of the research methods (2.), a recall of the definition of utopia/dystopia (3.), Corpus Delicti will be examined for its utopian - dystopian features (4.) and its visionary character with respect to the current Corona crisis management in France (5.)

\section{Research Methodology}

I will outline the common definition of the utopian and dystopian genre in precedent literature and examine utopian and dystopian features of Corpus Delicti keeping in mind precedent classic dystopian literature, especially Orwell's 1984 and Samjatin's My.

After the attempt to classify and to define the literary nature of Corpus Delicti, I will focus on its visionary, prophetic character with respect to the current Covid - 19 epidemic, pointing out the parallelism between what happens in Corpus Delicti and the French legislation in order to prevent and fight Covid-19.

\section{Recall of the definition of utopia and dystopia}

While in modern usage the term utopia refers to a "seemingly unfeasible plan", an "idea without a basis in reality (Duden, n.d.)", the literary genre of utopia is understood as the design of concepts of law, State and society as they should ideally be. 
Plato's "Politeia" (424-347 av. J.-C.) is considered one of the first utopian works of mankind, where he projects a socially tripartite society (workers, guardians and ruling philosophers) where justice, harmony and peace grant the smooth functioning of the State prioritizing collective interests to individual freedom.

Later, in 1516, the genre got its name "utopia" from Thomas More's work "Of the best State of the State, or of the new island Utopia" ("De optimo reipublicae statu, deque nova insula Utopia") (Hacker, 2008: 7) In this utopia individual property is abolished in favour of common property and all citizens live in equal conditions. Again, the interest of the state dominates individual aspirations, freedoms and claims.

Conditioned by the industrial revolution of the 19th century leading to the impoverishment of the working proletariat and a huge gap between the rich and poor as well as the totalitarian disasters of the 20th century, the positive, "sunny" utopian dreams turned into "black utopias" or "dystopias" which fear the destruction of humankind and human rights: "[...]Die 'schwarzen Utopien', die Dystopien, warnen vor einer ,, machbaren “ Zukunft, in der die Humanität des Menschen nicht verwirklicht, sondern zerstört wird (Hacker, 2008: 102)".

According to the contemporary definition by Elias, dystopias appear as one of the faces of utopias, the black one:

[...] Phantasiebild einer Gesellschaft, das Lösungsvorschläge für ganz bestimmte ungelöste Probleme der jeweiligen Ursprungsgesellschaft enthält, und zwar Lösungsvorschläge, die entweder anzeigen, welche Änderungen der bestehenden Gesellschaft die Verfasser oder Träger einer solchen Utopie herbeiwünschen oder welche Änderungen sie fürchten und vielleicht manchmal beide zugleich (Hacker, 2008: 8).

With this definition, utopias and dystopias (anti-utopias) become the two faces of the same coin.

Nicolas Bazin sees the dystopia like an utopia with a negative outcome: "La dystopie n'est pas, en effet, que la description d'une société de cauchemar, le contraire d'une utopie en somme, mais désigne la plupart du temps une 'utopie qui a mal tourné' (Bazin, 2019: 13)".

While dystopian writing originally drew its topics from the misery of the industrial revolution of the 19th century or the World Wars and totalitarian systems of the 20th century, today dystopias tend to express human's current fears about globalization, nuclear threat, technology, digitalization and environmental destruction.

Typical features of dystopian literature, which partly coincide with utopia, are the temporal or geographical displacement of the plot (isolation), the description of a perfect system (static), the striving for human eugenics, the establishment of a sanctioning apparatus in a totalitarian system, anti-individualism, the description of a realistic dark picture, and the appearance of a character who develops into an opponent of the system and thus becomes an anti-state outsider. Important representatives of dystopian literature are Yevgeny Zamyatin ("My"), Aldous Huxley (" A new Brave World") and George Orwell ("1984"), influenced by the inhuman atrocities of the 20th century, who paint black horror pictures of human society in their novels, in which only oppression, suffering and loss of freedom are to be expected.

\section{Examination of Corpus Delicti for utopian/dystopian features.}

At the beginning of 2020, the Corona epidemic broke out in Europe, caused by the SARS-CoV2 virus, and was qualified as a pandemic by the WHO as of 11 March 2020. When asked whether she had foreseen this pandemic at the time of writing Corpus Delicti, Juli Zeh denied this, but she points out that she transferred existing problems in society into the future adding 
exaggeration and features of totalitarism: "Ich wollte keine Zukunftsvision schreiben und sagen: In so und so viel Jahren sieht es so und so aus. Ich habe tatsächlich Dinge, die jetzt schon da sind, in ein fiktives System übertragen und ein bisschen überdreht. Vor allem habe ich den Totalitätsanspruch hinzugefügt (Schölderle, 2020: 53).“

In Corpus Delicti the boundaries between utopia/dystopia seem to merge, utopian as well as dystopian features complete each other.

\subsection{Utopian features in Corpus Delicti}

From the utopian genre, Corpus Delicti takes on aspects of "how it should ideally be": In the beginning comes the description of idyllic utopian life in a preserved nature, free from pollution: "[...] hier hat eine zur Ruhe gekommene Menschheit aufgehört, die Natur und damit sich selbst zu bekämpfen (Zeh, 2013: 13)".

Likewise seems "idyllic" the aim of the METHODE to guarantee every citizen a painless, disease-free and happy life without fear and stress. So Heinrich Kramer proudly declares that the METHODE has succeeded to guarantee happiness in a world exempt of illness and pain "Wir haben eine Methode entwickelt, die darauf abzielt, jedem Einzelnen ein möglichst langes, störungsfreies, das heißt, gesundes und glückliches Leben zu garantieren. Frei von Schmerz und Leid (Zeh 2013: 40)".

This apparently noble goal of happiness is also reflected in Mia Holl's face: "Ihr Gesicht strahlt jene besondere Anmutung von Sauberkeit aus [...] Den Ausdruck von Menschen, die ein Leben lang von Schmerz verschont geblieben sind (Zeh, 2013: 20)".

Corpus Delicti reveals, from the mere literary standpoint, clearly features of the utopian genre: The transposition of events into the future, but not clearly geographically delimited, as in most utopias (cf. Orwell's 1984 and Samjatin's My). Juli Zeh leaves the reader in the dark about the exact "when" and "where" of the story, just as there are no geographical details: "Dort, wo sie sich treffen, irgendwo inmitten des reflektierenden Dächermeers, also mitten in der Stadt, mitten am Tag und in der Mitte des einundzwanzigsten Jahrhunderts (Zeh, 2013: 14)".

The supremacy of the collective interest over that of the individual: "[...]In dem Punkt decken sich ihre Interessen mit jenen der METHODE, und auf diese Übereinstimmung stützt sich unser ganzes System (Zeh, 2013: 63-64).

Observing critically the ongoing destruction of the environment by pollution and human intrusion, the struggle of humans against illness and death, Juli Zeh partially produces an ideal world in which people no longer suffer, do not fall ill and live happily for a long time. But are they really happy ? Isn't the price to pay, to say, giving up personal freedom and selfdetermination, very high? This counterpart to apparent happiness leads us to the dystopian side of Corpus Delicti.

\subsection{Dystopian features in Corpus Delicti}

From dystopia, Juli Zeh takes on the "as it should not be, but society is in danger to become" pointing to a possible future loss of individual freedoms and rights even in our currently democratic society. The critical observation of the "here and now" leads her to fear that lack of vigilance and responsible participation in the democratic process may ease the way to intensified control, coupled with the violation of privacy and individual rights, in order to strengthen the State's power. This can happen in an imperceptible way, that citizens do not be aware of ongoing undemocratic processes until it becomes too late. 
With the objective of "awakening" she depicts in Corpus Delicti a perfect, totalitarian State, founded on the control of the human bodies, which its convinced supporter Heinrich Kramer compares to a perfect complex system of an organism: "[...] Zu diesem Zweck haben wir unseren Staat hochkomplex organisiert [...] Unser System ist perfekt (Zeh, 2013: 40)". In this totalitarian system, there is no privacy, the individual interest must give way to the collective interest in all circumstances: "Es besteht eine enge Verbindung zwischen dem persönlichen und dem allgemeinen Wohl...[...] (Zeh, 2013: 64)."

This conception of the collective body versus the individual citizen is mapped out in Corpus Delicti as a possible future design of society: The State, the METHOD, exercises its power of control over the perfect health of all individuals in the interest of the common good. This striving for perfect disease - and pain free existence for all seems to legitimise itself and appears as to be "well-intentioned".

The use of technical means of surveillance and control are self-evident to achieve this goal: Microchips in the arm, sensors in the toilets, X-rays, ultrasound, and magnetic resonance imaging contribute to the control of citizens, who have to report sleep, sport and nutrition datas, urine tests, blood pressure values, calorie consumption and substance soreness data on a regular basis (cf. Zeh 2013, 20-21).

However, it goes without saying that those citizens who do not regularly comply with all health checks and regulations need to be sanctioned or discarded, what is happening to Mia the more she opposes the system.

Thus literary dystopian features are clearly identifiable in Corpus Delicti keeping in mind Orwell and Samjatin: The existence of an apparatus of sanctions to enforce compliance with the rules and regulations proper to a totalitarian State, the use of science and technology serving repression and the existence of the outsider Mia Holl, who opposes progressively the system running through an internalised process and challenges the system by proving its fallibility: "Die Sache mit Moritz ist ein schwerer Schlag für unser Land. Zum ersten Mal hat sich die Methode als fehlbar erwiesen (Zeh, 2013: 246)".

But besides the classic totalitarian - technical dystopian features, I see a new form of dystopian features arising: the legal vacuity and arbitrariness, depicted in Corpus Delicti with strong recalls of legal contexts and the use of a rich legal terminology near to reality, such as penal sentences, court's trial, judge, lawyer, actor, defender, public prosecutor, evidence and many more.

But although the abundant legal references, there is no clearly drawn Constitution, no State organization, there are no named leaders of the State, no parties, no clearly ruled public organs, no precise rules of criminal procedure, power is diffusely embodied by the journalist and ideological fanatic, Heinrich Kramer. The power of the media thus seems to be above the legal system.

The judges Sophie and Hutschneider as well as the public prosecutor Bell determine the destiny of the accused, mostly by collusion between the prosecutor and the judge.

From a legal point of view, there are no legal guarantees for the citizens, no clear separation between the executive and the judiciary, no control functions of higher instances that decide anew on the correctness or not of a judgement, there is no legal certainty.

Juli Zeh, sensitive to law issues, waves into her novel legal and literary abilities, pointing the danger of using legal mecanismes to drift towards totalitarian methods of control, wiping away individual rights and guarantees. She calls the reader to keep the eyes open and not to feel perfectly secured even in a so called democratic system, which needs to be supported actively to avoid slipping towards totalitarianism. 
In this light Corpus Delicti, published in 2009, appears to be incredibly visionary and prophetical with respect to the current Covid-19 pandemic.

Similarly to what happens in Corpus Delicti, the highest judicial authorities seem to work hand in hand with the executive instead of exercising an impartial, objective control function. This realistic negative vision will be illustrated by the example of the legal handling of the Corona crisis in France.

\section{France - Management of Covid-19 epidemic}

The French Fundamental Law is composed of the so-called constitutional block, which consists of the French Declaration of Human Rights of 1789, the Preamble of the French Constitution of 27 October 1946, the Constitution of 4 October 1958 currently in force, and the Environmental Charter of 2004.

Article 4 of the Declaration of Human Rights of 1789 guarantees individual freedom, legitimising the French citizen to exercise his full liberties as long as these do not restrict or hinder other fellow citizens in their same liberties: "La liberté consiste à pouvoir faire tout ce qui ne nuit pas à autrui: ainsi, l'exercice des droits naturels de chaque homme n'a de bornes que celles qui assurent aux autres membres de la société la jouissance de ces mêmes droits". Any restriction of this freedom can be imposed exclusively by law: "Ces bornes ne peuvent être déterminées que par la loi".

In very exceptional situations only, article 16 of the French Constitution gives the France's President, after consulting the Chancellor, the Presidents of the two Houses of Parliament and the Constitutional Council, the possibility of taking exceptional measures when the institutions of the State, the independence of the nation, the integrity of the national territory or the fulfilment of international obligations are seriously threatened: "Lorsque les institutions de la République, l'indépendance de la Nation, l'intégrité de son territoire ou l'exécution de ses engagements internationaux sont menacés d'une manière grave et immédiate et que le fonctionnement régulier des pouvoirs publics constitutionnels est interrompu, le Président de la République prend les mesures exigées par ces circonstances, après consultation officielle du Premier ministre, des Présidents des Assemblées ainsi que du Conseil constitutionnel". But this constitutional provision is not suitable for a situation of health emergency equal to the current epidemic.

However, within France's law armoury there is the law No. 55-385 of 3 April 1955 which provides the possibility of declaring a temporary State of emergency in the event of an imminent threat to public order ${ }^{1}$ or a serious event causing a state of public emergency ${ }^{2}$, which allows the government to state by decree without the participation of Parliament for a maximum period of 12 days. This law could certainly have applied to the Covid-19 epidemic without the need to create a new law. Thus the management of the Corona crisis could have been undoubtedly ruled under this existing law.

Nonetheless the French Government exploited the situation of health emergency and of people's generalized fear to adopt a specific new law n² 2020-290 of 23 March 2020 in order

\footnotetext{
1 "Cas de péril imminent résultant d'atteintes graves à l'ordre public".

2 “Cas d'événements présentant, par leur nature et leur gravité, le caractère de

calamité publique".
} 
to enhance its powers, impacting heavily individual rights of citizens. This law, incorporated in the "Code de la santé publique", is to remain in force for the time being until 1 April 2021, but a project submitted to Parliament in January 2021 tends to extend the application of this law of exception until 31st of december 2021 (Assemblée Nationale, 2021).

Thanks to this worrisome law the executive eliminates over long periods any control and intervention by the Parliament and confers on the Government extended powers to restrict or eliminate individual rights of citizens in the name of the fight against Covid-19. This means that during this exceptional period the Minister of Health can take any measure he deems necessary to contain the threatening consequences of the epidemic for the health of the population $^{3}$ : restriction up to total suspension of freedom of movement, closure of shops, establishments, institutes, clubs, premises of any kind, prohibition of all meetings, confiscation of goods or persons necessary to fight the crisis, imposed price regulations as well as other measures to restrict any entrepreneurship.

The formulation of the possibility to take "any necessary measure" is particularly broad and vague, and seems to give the government free reign without any control mechanism (OJP, 2020): "En cas de menace sanitaire grave appelant des mesures d'urgence, [...]le ministre chargé de la santé peut[...] prescrire dans l'intérêt de la santé publique toute mesure proportionnée aux risques courus et appropriée aux circonstances de temps et de lieu..."

These far-reaching powers of the executive are limited only vaguely, and are subject to subjective interpretation, by the final provision of Article $3131-15,10^{\circ}$ of the "Code de la santé publique", which requires that all measures restricting freedom need to be proportionate to the health risks and adapted to the temporal and local circumstances. As soon as they are no longer necessary, they must be lifted immediately: "Les mesures prescrites en application des $1^{\circ}$ à $10^{\circ}$ du présent article sont strictement proportionnées aux risques sanitaires encourus et appropriées aux circonstances de temps et de lieu. Il y est mis fin sans délai lorsqu'elles ne sont plus nécessaires".

This final provision cannot be considered sufficient to prevent abuse of power and abusive restriction of individual freedom in France.

According to French case law, measures restricting freedom are considered lawful if they are necessary, appropriate and proportionate: "[...] résulte que les mesures restrictives des droits et libertés ne sont légales que si elles répondent aux trois exigences inhérentes au principe de proportionnalité : la nécessité, l'adéquation et la proportionnalité (Dalloz Actualité, 2020)."

Furthermore there will be no constitutional control over the respect of these principles during the period of emergency state: Particularly worrying in this regard is the decision of the French Constitutional Court not to examine any of the measures urgently adopted by the government for their possible unconstitutionality during the period of the health crisis (Roudier, 2020). This means no control of the necessary, appropriate and proportionate character of measures taken by the Government.

Nicolas Baverez - lawyer, senior civil servant in the State administration and politician criticises the extreme concentration of power in the hands of the President as well as the very extensive restrictions on individual liberty in the context of the Covid-19 crisis: "La France fait cependant exception par la concentration extrême des décisions entre les mains du président de la République comme par l'ampleur des restrictions aux libertés (Baverez, 2020)." The last evidence of this undemocratic tendency is the decision taken by the Defense Council, excluding even a certain number of Ministries in violation to law, to suspend the freedom of

3 Art. L3131-1 al. 1 du code de la santé publique. 
movement outside France since 30th of January 2021 without determination of time limit. (Gouvernement.fr, 2021).

This picture recalls the worrying restriction of individual rights for the sake of health in Corpus Delicti: nebulosity and arbitrary power without any counter power, insofar as there is no control organ and no resistance by the population.

\section{Conclusion}

In addition to depicting an utopian, pure, healthy environment in which pollution, climate change, micro-particles in the lungs, smog, pesticides, the hole in the ozone layer, groundwater contamination, toxic waste, nuclear waste disposal, etc. belong to the past and where men and nature live in peaceful symbiosis, Corpus Delicti warns against totalitarian tendencies - which can arise in today's democracies, too - with the help of technical achievements and an arbitrary, unclearly drawn legal situation that violates people's privacy: All this indicates a combination of utopia/dystopia, which is made up of elements of positive and negative utopia, totalitarian and scientific/technical dystopia, as well as newly added elements of legal dystopia. An example of proximity between Juli Zeh's dystopian picture and the current reality, confirming the strong visionary character of Corpus Delicti, is the management of Covid -19 crisis in France which should invite all of us to keep our eyes open when it comes to breaches in our individual rights.

\section{References}

Affective Societies. (2020). Santé! Literatur als Möglichkeitsraum: Juli Zehs „,Corpus Delicti. Ein Prozess ". SFB Affective Societies. https://affective-

societies.de/2020/impulse/sante-literatur-als-moeglichkeitsraum-juli-zehs-corpus-delictiein-prozess/

Assemblée Nationale. (2020, December 21). Projet de loi $n^{\circ} 3714$ instituant un régime pérenne de gestion des urgences sanitaires. Assemblée Nationale. https://www.assemblee-nationale.fr/dyn/15/textes/115b3714_projet-loi

Assemblée Nationale. (2021, January 14). PROJET DE LOI. Www.assemblee-Nationale.fr. https://www.assemblee-nationale.fr/15/textes/3739.asp\#D_autorisant_la_prorogation_de

Baverez, N. (2020, November 30). Assurer la sécurité sans sacrifier la liberté. https://www.nicolasbaverez.com/2020/11/30/assurer-securite-sacrifier-liberte/

Bazin L. (2019). La dystopie. Presses Universitaires Blaise Pascal, Dl.

Conseil Constitutionnel. (2018). Déclaration des Droits de l'Homme et du Citoyen de 1789.

Conseil Constitutionnel. https://www.conseil-constitutionnel.fr/le-bloc-deconstitutionnalite/declaration-des-droits-de-l-homme-et-du-citoyen-de-1789

Conseil constitutionnel. (1946). https://www.conseilconstitutionnel.fr/sites/default/files/201903/20190307_preambule_constitution_1946.pdf

Dalloz Actualité. (2020, September 23). Covid : les mesures restrictives de liberté résistentelles au test de proportionnalité ? - Administratif | Dalloz Actualité. https://www.dallozactualite.fr/node/covid-mesures-restrictives-de-liberte-resistent-elles-au-test-deproportionnalite\#.X80mrnhKhQI 
Deutschlandfunk. (2009, May 20). - Gesundheitsdiktatur als Zukunftsvision. https://www.deutschlandfunk.de/gesundheitsdiktatur-alszukunftsvision.700.de.html?dram:article_id=84085

Duden. (n.d.). Duden | Utopie|Rechtschreibung, Bedeutung, Definition, Herkunft. Retrieved January 6, 2021, from https://www.duden.de/rechtschreibung/Utopie

Encke, J. (2020, June 2). Neues Buch von Juli Zeh: Bloß nicht bewegen. FAZ.NET. https://www.faz.net/aktuell/feuilleton/buecher/rezensionen/belletristik/neues-buch-vonjuli-zeh-ein-buch-ueber-die-corona-pandemie-16793883.html

Gernert, J. (2009, March 24). Plädoyer gegen die Fitness-Diktatur. Stern.de. https://www.stern.de/kultur/buecher/interview-mit-juli-zeh-plaedoyer-gegen-die-fitnessdiktatur-3432820.html

Gicquel, J. E. (2020, April 7). La loi organique Covid-19 et l'irrespect non sanctionné de la Constitution | La base Lextenso. Www.labase-Lextenso.fr. https://www.labaselextenso.fr/gazette-du-palais/GPL377e4

Gouvernement.fr. (2021, January 29). Info Coronavirus COVID-19 - Les actions $d u$ Gouvernement. Gouvernement.fr. https://www.gouvernement.fr/info-coronavirus/lesactions-du-gouvernement

Hacker, C. (2008). Psychologie und Utopie. http://othes.univie.ac.at/2642/

Höffe, O. (2011). 1. Einführung in Platons Politeia. Platon: Politeia, 1-20. https://doi.org/10.1524/9783050089935.1

Ilija Trojanow, Zeh, J., Schad, S., \& Margrit Osterwold. (2009). Angriff auf die Freiheit Sicherheitswahn, Überwachungsstaat und der Abbau bürgerlicher Rechte. Hörbuch Hamburg.

Le Monde du Droit. (2020, December 14). Les avocats parisiens inquiets des menaces qui pèsent sur les libertés des français - LE MONDE DU DROIT : le magazine des professions juridiques. Www.lemondedudroit.fr.

https://www.lemondedudroit.fr/institutions/71948-avocats-parisiens-inquiets-menaceslibertes-francais.html

Légifrance. (2020a, March 27). Publications officielles - Journal officiel - JORF $n^{\circ} 0072 d u$ 24/03/2020. Www.legifrance.gouv.fr.

https://www.legifrance.gouv.fr/download/pdf?id=KY9SZZfQdcIRn_N8Kc1gxuN7Pce5 JP_lubW2AuKlCjU=

Légifrance. (2020b, May 11). Titre III : Menaces et crises sanitaires graves (Articles L3131-1 à L3136-2) - Légifrance. Www.legifrance.gouv.fr. https://www.legifrance.gouv.fr/codes/section_lc/LEGITEXT000006072665/LEGISCTA 000006155031/\#LEGISCTA000041748552

Massar, J. (2014). Machtbeziehungen im Roman Corpus Delicti . Ein Prozess von Juli Zeh. Universität Wien. http://othes.univie.ac.at/31899/1/2014-02-03_0421520.pdf

MAZ. (2020, May 25). Corona: Juli Zeh warnt vor vermeintlicher Sicherheit auf Kosten von Freiheit. MAZ - Märkische Allgemeine. https://www.mazonline.de/Brandenburg/Corona-Juli-Zeh-warnt-vor-vermeintlicher-Sicherheit-aufKosten-von-Freiheit

MENECEUR, Y. (2020, November 29). COVID-19 \& Traçage numérique : comment concilier santé et libertés individuelles ? Les Temps Électriques. https://lestempselectriques.net/index.php/2020/11/29/covid-19-tracage-numeriquecomment-concilier-sante-et-libertes-individuelles/ 


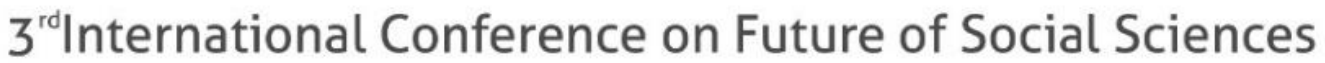 \\ 5 - 7 March 2021 \\ BERLIN, GERMANY}

Müller-Dietz, H. (2011). Zur negativen Utopie von Recht und Staat - am Beispiel des Romans ,C Corpus Delicti“ von Juli Zeh. JuristenZeitung, 66(2), 85-95.

https://www.jstor.org/stable/20830380?read-now=1\&seq=1\#page_scan_tab_contents

OJP. (2020, May 13). L'État de droit déstabilisé par l'état d'urgence sanitaire : menaces et encadrements. Justice-Penale. https://www.justicepenale.net/post/l-\%C3\%A9tat-dedroit-d\%C3\%A9stabilis\%C3\%A9-par-1-\%C3\%A9tat-d-urgence-sanitaire-menaces-etencadrements

Passard, C. (2020). Laurent Bazin, La dystopie. Lectures. http://journals.openedition.org/lectures/40027

Pena, A. (2020, December 1). La liberté individuelle face au Covid-19 : l'adaptation des garanties de l'article 66 de la Constitution aux circonstances d'urgence sanitaire (1re partie). Actu-Juridique. https://www.actu-juridique.fr/constitutionnel/la-liberteindividuelle-face-au-covid-19-ladaptation-des-garanties-de-larticle-66-de-laconstitution-aux-circonstances-durgence-sanitaire-1re-partie/

Pungračič, D. (2012). Diplomarbeit "Der Anti - Utopische Roman mit der Analyse des Romans Corpus Delicti von Juli Zeh. Universität Maribor.

Roudier, K. (2020, April 6). Dalloz Actu Étudiant. ; Dalloz. https://actu.dalloz-etudiant.fr/lebillet/article/un-nouveau-repli-du-conseil-constitutionnel-dans-son-role-decontrepoids/h/a1247a77d164c980639f8913ab0b

Schölderle, T. (2020). Gesundheit, Diktatur und Dystopie. Einsichten Und Perspektiven, 3/20, $40-54$.

https://www.blz.bayern.de/epaper/Einsichten_und_Perspektiven_3_2020/files/assets/bas ic-html/page-40.html

Zeh, J. (2013). Corpus Delicti : ein Prozess. Btb Verlag, 8. Auflage. (Original work published 2009)

Zeh, J., \& Btb Verlag (Tb. (2020). Fragen zu “Corpus Delicti.” München Btb. 